\title{
THE VOICES OF INDONESIAN STUDENTS ON THE USE OF ENGLISH Translation OF THE Holy QURAN aS AN AUTHENTIC Material RESOURCE TO TEACH READING
}

\author{
Puji Sumarsono \\ University of Muhammadiyah Malang \\ pujisumarsono@gmail.com
}

\begin{abstract}
English translation of the Holy Quran has been utilized as an authentic material to teach and learn English (Sumarsono, 2016). A skill which is directly related to this issue is reading through a genre based-approach by exploring narrative texts in the Holy Quran (Sumarsono, 2017). Considering that these previous researchers have developed teaching methodology and also teaching materials, it is crucial to understand the students' voices concerning the use of this methodology and materials. The importance of this study is to provide feedback and improve the use of this methodology and materials. This study applied qualitative as it intended to understand and describe the phenomenon deeply. An instrument which was applied was an interview and the interviewees were the students who were joining a class using this methodology and teaching materials. The students have positive views on the use of English Translation of the Holy Quran as an authentic material resource to teach reading. This methodology has two crucial roles in the development of knowledge and faith.
\end{abstract}

Keywords: Voices, Authentic Materials, English translation of Quran

\section{INTRODUCTION}

Teaching materials have a crucial role in the language classroom because they are the resources used by the teacher to facilitate teaching and learning occur both inside and outside of the classroom (Castillo Losada, Insuasty \& Jaime Osorio, 2017). Nowadays, teaching materials in English Language Teaching (ELT) are divided into two, artificial and authentic materials. Those kinds of materials are totally different from each other. Artificial is intentionally constructed for language teaching purposes, but authentic is directly taken from daily life sources in which it is not constructed for ELT purposes. Nunan (2004: 49) views authentic materials as samples of spoken and written language that have not been specifically produced for the purpose of language teaching.

The use of authentic materials in ELT remains problems and debate among scholars and teacher as well. Rahman (2014) identifies that a heated debate started on the issue of the type of material which is really categorized as authentic. In contrast, there are many different definitions in which most of them highlight different aspects of the 'authentic' term.

Sarapli (2011) claimed that the aim of using authentic materials is to prepare students for their social lives. The language which is learned should be realistic as it is difficult to get accurate material which satisfies students' needs. It bridges between the current activities in the classroom and real life in society. According to Lamier \& Schleicher (in Sarapli, 2011), the use of authentic materials for ELT provides some benefits. First, learning can be enhanced by the use of texts of particular interest to a class. Second, variety and spontaneity will increase in classes that introduce authentic materials in ELT. Then, exposure to a variety of vocabulary and structures will occur. Third, students will capitalize on their prior cultural and schematic knowledge to contrast target situations and genres with those of their own culture. Buendgens-Kosten (2014) argues that it is often assumed that authentic texts provide better linguistic models than non-genuine texts.

In spite of the debate among scholars on the use of authentic materials for English language teaching (ELT), there have been a lot of researches and practices to use authentic materials in ELT. They have been promoted worldwide by teachers and scholars through this debate (Ravalovich, 2014). Sumarsono (2016) has already put the idea of authentic material for ELT into practices. He utilized the 
translation of the Holy Quran to teach and learn reading subject in a higher education setting. Sumarsono (2018) even identified the genre of text in the English translation of the Holy Quran. It was found a lot of narrative texts in the Holy Quran.

Sumarsono (2018) proposes a methodology of teaching and learning reading using English translation of the Holy Quran as an authentic material resource. It covers the objectives of teaching and learning reading, the materials of teaching and learning reading, the procedure of teaching and learning reading. The objective is to give students comprehension about different types of texts in Holy Quran and the main ideas/topics, details, relationships between sentences and paragraphs, as well as the rhetorical structure of the texts so that they are able to distinguish and explain kinds of text as well as comply the content of Holy Quran.

The materials of teaching and learning reading are texts of the English translation of Holy Quran which are translated from Arabic into English by Abdullah Yusuf Ali.

Table 1: Samples of text types available in the Holy Quran

\begin{tabular}{|c|c|c|c|c|}
\hline Types of text & Topic & Chapter & Surah & Verse \\
\hline Narrative & $\begin{array}{l}\text { History of the first assassination in } \\
\text { the world }\end{array}$ & 6 & Al-Maidah & $27-32$ \\
\hline \multirow[t]{3}{*}{ Descriptive } & Description of Heaven & 1 & Al-Baqarah & 25 \\
\hline & & 27 & Ar-Rahman & $56 \& 70$ \\
\hline & & 30 & Al-Ghasyiyah & $8-16$ \\
\hline Expository & The procedure of taking ablution & 6 & Al-Maidah & 6 \\
\hline Argumentative & The importance of qisas & 1 & Al-Baqarah & $178-179$ \\
\hline
\end{tabular}

The procedure is divided into 6 steps. First, the lecturer decides the version of the English translation of the Holy Quran which will be used. Second, the students are equipped with English translation of the Holy Quran (Yusuf Ali version). Third, the lecturer explains the genre of text. Fourth, a class divided into a group of 3 students. Each group should read a different chapter of Holy Quran translation and classify them according to the four types of text. Fifth, each group presents the result of their project and other groups, as well as the lecturer, give feedback on it. Last, for structured individual and independent learning, the students should read one day one page.

However, this methodology has not evaluated yet. According to Holland (in Phillips, Balan \& Manko, 2014), the evaluation process should cover six standards. First, a differentiated evaluation approach based on the teacher's level of development. Second, a collaborative approach that considers the teacher's goals, progress towards achieving those goals, and the implications of that progress. Third, multiple observations by more than one individual. Fourth, formative as well as summative evaluation, with greater emphasis on the formative approach. Fifth, a focus on school goals as well as individual goals. Last, transparent evaluation policies that are clearly articulated and defined, and understood by teachers and administrators. It is, therefore, the teacher has not received any feedback to improve this methodology. One of the easiest ways to understand the values of a methodology is by asking the students' opinion regarding what they have experienced while they are learning using this methodology. It is, therefore, the research question is "What are the students' opinions on the use of English translation of the Holy Quran as an authentic material resource to teach Reading? This evaluation in term of students' opinions is crucial as it would be able to get feedback from the students and finally improve the methodology (objectives, material, and procedure) of teaching and learning reading using Translation of Quran as an Authentic Material. 


\section{MATERIALS AND METHODS}

The research design applied was a qualitative research design. The subjects of this research were 24 students of Reading III. The instruments used in this research were interview and observation by conducting the video recording and note taking while the lecturer teaches Reading III. The interview and observation were conducted to find the students' opinion so that it could provide feedback regarding the teaching learning using Translation of the Holy Quran as an Authentic Material.

The researcher is the main instrument of this research. In addition, this research also used the triangulation method to get the more valid data on the problems and solutions of the implementation of English translation of the Quran as an authentic material for teaching reading. The collected data were then analyzed by selecting the necessary data related to the topic being investigated, sorting out the data into a table of data presentation, analyzing the data to find out the answer of the statement of the problems, writing the result of the research descriptively, and drawing a conclusion.

In addition to the procedure of data analysis, the researcher defined an opinion as it was stated by Liu \& Zhang (2012) that an opinion is a positive or negative sentiment, attitude, emotion or appraisal about an entity or an aspect of the entity from an opinion holder. The orientations of the opinion are categorized into three, positive, negative and neutral. In addition, Lani \& Nurjanah (2014) simply argued that positive opinion means supporting and negative means rejecting. In this research, therefore, opinion is categorized into positive when it supports the idea, it is categorized as negative when it rejects the idea, and it is categorized as neutral when it has neither positive nor negative.

\section{RESULTS AND DISCUSSION}

The results are presented according to some sub-topics such as; general opinion, the advantages and the difficulties, opinions to the procedures of teaching-learning activities, suggestions for better improvement. Among twenty-two students, eighteen students gave positive opinions. They said that teaching reading using the English translation of the Holy Quran is useful, interesting and excellent, amazing, incredible, good, able to motivate them to read the Quran more often, increase insight and vocabulary mastery. However, only four students gave negative responses. They claimed that it was difficult and not effective.

The advantages of this methodology are able to improve vocabulary mastery and reward from God, improve religious insight, motivate students to read, hone a reading skill, motivate students to pray diligently, improve students' ability in reciting Quran, learn old English, touch students' heart, get wisdom. While the difficulties that students faced were difficult to understand vocabulary and conclude the lesson of the text, limited time to do the activities, and installing the Holy Quran application.

Related to the 6 steps of the procedure of teaching activities, here are their opinions. First, when the lecturer decided the version of the English translation of the Holy Quran which will be used, all of the students strongly agreed as it was crucial to have the same perception and resources to study. Two reasons for this agreement were it was assumed that the lecturer knows more on the materials that would be taught and different text will make students and confuse to learn. For example, when the lecturer explained about a certain text in the English translation of the Holy Quran, two students had been confused to understand the lecturer's explanation because they used a translation which was different from the lecturer and other 22 students. When the lecturer explained the meaning of the word "thou" and "thy" in surah Al-Baqarah verse 35, the two students were confused because those words were not available in the text they had. After the lecturer checked the text, it was found that the two students had different version of the translation.

Similar perception between teacher and students in the initial teaching and learning process could lead the success of teaching and learning. This stage can be described as teacher/students partnership. Barker \& Moroz (1997) claimed that students/teacher partnership is a compulsory association between two parties who participate in a joint venture in the pursuit of learning. It implicitly states that teaching and learning objectives could be achieved well when students and also teacher as well work together and understand each other. Second, when the students were equipped with the English translation of the Holy 
Quran (Yusuf Ali version), some of them agreed since the language is beautiful, unique and excellent. There are numerous old vocabularies in it. However, some of them said that it was more difficult than other versions of translation so that some of them open Tafseer to check their understanding. Siddiek (2012) claimed that the Quran is an untranslatable text. It is, however, useful to use some interpretations of its (Tafseer). The benefits of Tafseer are to facilitate its meaning to make the readers understand it, defending away all fabricated distortions made by the enemies of Islam against the Quran and its interpretations, and to enlighten non-Muslim foreigners- especially in this age based on propagandaabout the realities of Islam: the richness of its values and teachings.

Third, when the lecturer explained the genre of text, they said that it was a very good step so that they can understand and compare each kind of text in the Holy Quran. In addition, when the lecturer asked them to find some examples of kinds of text, most of them claimed that it was effective to learn, able to add more insight on kinds of text, and challenging as they had never done it before. In contrast, only some students said that it was a difficult activity.

Fourth, when the class was divided into a group of 3 students and each group should read a different chapter of Holy Quran translation and classify them according to the four types of text, most of the students agreed and felt that it worked well because they can share each other and know more kinds of text instead of they read by themselves. This working group also helped them to have a question and answer when they do not understand the text. In some points, however, some students indicated that it was not effective if only one student who worked in a group and members of the group cannot work together.

This teaching and learning scenario can be identified as cooperative learning. Sonthara \& Vanna (2009) explained that cooperative learning means that students learn together in structured groups so that each member in the group must succeed. Besides, students work together to study and are responsible for the learning of their members. Jacobs (2004) proposed eight principles of cooperative learning such as; heterogeneous grouping, collaborative skills, group autonomy, simultaneous interaction, equal participation, individual accountability, positive interdependence, and cooperation as a value. As cooperative learning has some types such as; STAD, TAI, and Jigsaw, the activities conducted by the lecturer and the students using English Translation of the Holy Quran can be classified as jigsaw. Aronson (2018) said that Jigsaw is an efficient way to learn materials because each Group member must work together as a team to accomplish a common goal.

Fifth, when the lecturer asked each group presented the result of their project and other groups, as well as the lecturer, gave feedback on it, all students agreed and happy as they can learn and share each other, strengthen their understanding because students learn it many times from different presenters, train students to speak or present in front of class, improve students' motivation, understand the students' comprehension and problems in learning.

Last, for structured individual and independent learning which demanded the students to read one day one page and find the difficult vocabulary, they were finally so happy because it increased their English vocabulary mastery, made them remember Allah every time and read The Holy Quran every day, whenever, and wherever. However, for the students who had no Android, it made them upset as they cannot read anytime. They should open it in their computer or printed version.

The difficulty to understand the English Translation of the Holy Quran is well understood as the translators also face many linguistic difficulties when they translate the Holy Quran into English. Ali et al. (2012) mention the difficulties include lexical, syntactic, Semantic, metaphor, metonymy, ellipsis, polysemy. Emara (2013) also notes that many words are not allocated an accurate meaning by Quranic reviewers. The same word in the same context might be exposed to have numerous literal and figurative meanings. Besides, Some English words do not have the same expressive power as their Arabic counterparts. It is, therefore, many readers are confused to understand the translation. This difficulty is also found by reviewers of English Translation of the Holy Quran that Quran translations written in oldfashioned English with difficult vocabulary (islam.stackexchange.com). 


\section{CONCLUSION}

Students of English Department of UMM have positive views on the use of English Translation of the Holy Quran as an authentic material resource to teach reading. This methodology has two crucial roles on the development of knowledge and faith. In term of knowledge, it can increase students' knowledge both on Islamic lessons and English vocabulary. In term of faith, after students read every day and understand the texts, it can also improve students' faith to Allah in which it can improve their good deeds in daily life. However, these benefits at the same time also bring difficulties such as difficulty in understanding the lesson and vocabulary. These difficulties should be and have already been solved so that will not disturb the teaching-learning activity and provide new insight in teaching English using religious approach.

\section{ACKNOWLEDGEMENT}

The author thanks to Directorate of Research and Community Service (DRCS), University of Muhammadiyah Malang (UMM) for the financial support so that this research could be finished well. However, any opinions, findings, and conclusions or recommendations expressed in this material are those of the researcher and do not necessarily reflect the views of the DRCS UMM.

\section{REFERENCES}

Ali, A. et al. (2012). Some Linguistic Difficulties in Translating the Holy Quran from Arabic into English. International Journal of Social Science and Humanity, Vol. 2, No. 6,

Aronson, E. (2018). https://www.jigsaw.org/overview/

Barker, R. G., \& Moroz, W. (1997). Student and teacher perceptions of teaching/learning processes in classrooms: how close is the partnership?. Australian Journal of Teacher Education, 22(1). http://dx.doi.org/10.14221/ajte.1997v22n1.3

Buendgens-Kosten, J. (2014). Authenticity. ELT Journal, Volume 68, Issue 4, 1. 457-459, https://doi.org/10.1093/elt/ccu034

Castillo Losada, C. A., Insuasty, E. A., \& Jaime Osorio, M. F. (2017). The impact of authentic materials and tasks on students' communicative competence at a Colombian language school. PROFILE Issues in Teachers' Professional Development, 19(1), 89-104. https://doi.org/10.15446/profile.v19n1.56763.

Https://Islam.Stackexchange.Com/Questions/613/Why-Are-Quran-Translations-Written-In-OldFashioned-English-With-Difficult-Vocab

Jacobs, G. 2004. Cooperative learning: theory, principles, and techniques. Retrieved from https://www.researchgate.net/publication/254097701_COOPERATIVE_LEARNING_THEORY _PRINCIPLES_AND_TECHNIQUES

Lani, O.P. \& Nurjanah. (2014). Opini Mahasiswa terhadap Pelaksanaan Kuliah Kerja Nyata (Kukerta) di Universitas Riau. Retrieved from https://jom.unri.ac.id/index.php/JOMFSIP/article/view/2444/2380

Liu, B. \& Zhang, L. (2012). Survey of Opinion Mining and Sentiment Analysis Retrieved from http://www.cs.unibo.it/ montesi/CBD/Articoli/SurveyOpinionMining.pdf

Nunan, D. (1999). Second Language Teaching and Learning. Boston: Heinle and Heinle Publishers.

Phillips, K., Balan, R. \& Manko, T. (2014). Teacher Evaluation: Improving the Process. Transformative Dialogues: Teaching \& Learning Journal Volume 7 Issue 3 .

Rafalovich, M. (2014). Reconsidering authenticity in ESL written materials. Hawaii Pacific University TESOL Working Paper Series 12, 96-103.

Rahman, R. (2014). A Case for Authentic Materials in Language Teaching. The Dialogue. IX (2). 206215

Sarapli, O. (2011). The Use of Authentic Materials in the Second Language Classrooms: Advantages and Disadvantages. Retrieved from http://dergiler.ankara.edu.tr/dergiler/27/1832/19277.pdf 
Siddiek, A.G. (2012). Viewpoints in the Translation of the Holy QURAN. International Journal of Applied Linguistics \& English Literature. Vol. 1 No. 2; July 2012. Pp 18-25. URL: http://dx.doi.org/10.7575/ijalel.v.1n.2p.18

Sonthara, K. \& Vanna, S. 2009. Cooperative learning: Theory \& Practice (A new guide for teachers). Retrieved from http://www.kapekh.org/files/report_file/38-en.pdf

Sumarsono, P. (2018a). Authentic narrative texts in English translation version of Holy Quran: A genrebased approach. Indonesian EFL Journal, 4(1), 65-72. DOI: 10.25134/ieflj.v4i1.801.

Sumarsono, P. (2018b). Methodology of Teaching and Learning Reading Using English Translation of Holy Quran as an Authentic Material Resource. The Social Sciences. 13 (2). 